\title{
Financial Feasibility Study of Liquid Smoke Industry from Palm Oil Empty Fruit Bunch in Mesuji Regency, Lampung Province
}

\author{
Erdi Suroso $^{1, *}$, Wisnu Satyajaya ${ }^{1}$, Tanto Pratondo Utomo ${ }^{1}$, Laila Julianti ${ }^{1}$
}

\begin{abstract}
The objective of this research was to examine the feasibility of liquid smoke production from palm ail empty fruit bunch (EFB). This research was a survey with expert respondents to collect primary data while literatures and reports study as secondary data. The result of study showed that the liquid smoke industry from EFB was feasible to be developed with eligibility criteria Rp. $991,486,765$ of NPV ; 2.50 of Net B/C; $36.59 \%$ of IRR ; and 2.83 years of PBP. The result of sensitivity analysis showed that the liquid smoke industry from EFB more sensitive for liquid smoke price decerasing than raw material and other inputs price increasing.
\end{abstract}

Keywords - Financial Feasibility, Liquid Smoke, EFB.

\section{INTRODUCTION}

$\mathbf{P}$ ALM OIL oil industry is one of the important industries in Indonesia. This industry processes fresh fuit bunch of palm (FFB) into crude palm oil (CPO), palm kernel oil (PKO), and also side product such as empty fruit bunch (EFB), shells, and fiber. EFB consists of organic materials, such as $24 \%$ of hemicellulose, $40 \%$ of cellulose, $21 \%$ of lignin, and $15 \%$ of ash and other components [1], therefore it reduces the environment quality if there is no adequate and appropriate handling. For example, a CPO Factory with capacity of 100,000 tons of FFB/year will produce 6,000 tons of shells, 12, 000 tons of fiber, and 23,000 tons of EFB [2] [3]. Nowaday, shells and fiber are used for boiler intake, meanwhile EFB is used mostly as raw material for fertilizer. The problem, if EFB were used as fertilizer, it takes time because it organic materials are complex substances.

Another EFB alternative utilization is as raw material for liquid smoke using pyrolysis proces [3]. Pyrolysis is a thermochemical decomposition of organic material at elevated temperatures in the absence of oxygen (or any halogen). It involves the simultaneous change of chemical composition, physical phase, and irreversibility. The word is coined from the Greek-derived elements pyro "fire" and lysis "separating" [5].

Liquid smoke produced from EFB utilization provides value added products because it contains phenolic acids and carbonyl compounds which can inhibit the growth of bacteria. Hence, the liquid smoke can be utilized in various sectors namely food sectors, industrial estates, and manufacturing industries. Liquid smoke in food sectors can be used as preservatives in foods such as fish, meat, noodles which can last up to two months. Liquid smoke in the industrial sector in the plantation can be used as rubber field latex coagulant, to eliminate strong odors also improve the quality of rubber produced. Liquid smoke in the manufacturing sector is used as a coating timber by smeared to be resistant to termite attack and provides greater color glazed on the product [5], [6].

The potential consumer of liquid smoke is the natural rubber industry in which Lampung Province as one of the main rubber producers in Indonesia. The area of rubber plantations in Lampung Province reached 241,379 ha with production of 169,004 tons of rubber in 2014 [7]. Based on this condition, a study of financial feasibility to analyze the prospects of industrial liquid smoke in Lampung Province is needed to be done, along with sensitivity analysis. The results of this research might be a reference for development of liquid smoke industry made from EFB that can become sustainable to be developed in Lampung Province.

\section{Methodology}

This research was conducted in the Mesuji Regency from February 2016 until May 2016.

The method used in this study was a survey method. The research used both primary and secondary data. The former was obtained directly from expert respondents through interviews and questionnaires while the remaining was collected through literature or reports from related government institutions.

The analysis tools in this research were the business analysis: Net Persent Value (NPV), Inceremental Rate of Return (IRR), Net Benefit Cost Ratio (Net B/C), Pay Back Period (PBP) and sensitivity analyzes [9]. The sensitivity analyzes performed the analysis against all the possibilities that would happen as lower revenue and rise in prices of raw material and others.

\section{RESUlTS AND DISCUSSIONS}

\section{A. Description of Study Area}

Mesuji regency is one of the regencies in Lampung Province. This regency is a development region from Tulang Bawang regency based on Indonesia Law No. 49 of 2008. Geographically, Mesuji regency located at $5^{\circ}-6^{\circ}$ south latitude and $106^{\circ}-107^{\circ}$ east longitude. Mesuji has two major rivers, namely Mesuji river and Buaya river which empties into the Java sea. It also has a role as the East gateway to the Jalintim (East Trans Sumatera) in and out to the Lampung province.

Mesuji regency directly bordered the various regions as follow: 
- Ogan Ilir regency, South Sumatra Province in the north;

- Mesuji regency and Mesuji barat rency of South Sumatra Province in the south;

- Ogan Komering Ilir regency, South Sumatra Province in the east;

- Ogan Komering Ilir regency, South Sumatra Province in the west.

Mesuji has total area of $2,184 \mathrm{~km}^{2}$. It consists of 7 (seven) districts and 75 villages, with the majority of regions in the form of low-lying area whic is suitable for agriculture and plantations. One of the plantation competitive products at Mesuji District is palm oil. This regency accounts as the largest production of palm oil in Lampung Province with the amount of 221766 tons per year of the total production of 539.829 tons per year [10]. Based on its geographically characteristics, currently, there are several agro-industries especially private enterprises which are growing fast in the commodities of palm oil, rubber, and tapioca industries.

Besides palm oil, a commodity which has cultivated in Mesuji District is rubber. Usually, rubber plantations in Mesuji district are managed by smallholder estates. Based on data from the government of Mesuji District, $80 \%$ (majority) of the residents are farmers, including rubber farmers. Mesuji itself included as a part of Lampung Province as the central of the national rubber manufacturer rubber production accounted for 27256 tons per year of total production which is written to 169004 Lampung province per year [11]. This Fig. actually was an accumulation of the total production of smallholder estate, Perkebunan Besar Negara (big national companies) and Private Plantation, but the Fig. s of national and private plantation were null. This fact indicated that the production of rubber in Mesuji district was still dominated by smallholder or peasant.

\section{B. Basis of Liquid smoke production}

The financial feasibility study was conducted on the production capacity of 1.200 tons of EFB (using 3 pyrolysis reactors, each capacity of $200 \mathrm{~kg}$ of EFB) with 3 hours operation time, 2 times per day production, and 8 hours per day of working hours. The pyrolisis process of EFB produced liquid smoke and other materials in a day: $240 \mathrm{~kg}$ of liquid smoke, 24 litres of tar, and $934 \mathrm{~kg}$ of charcoal respcctively (Fig. 1)

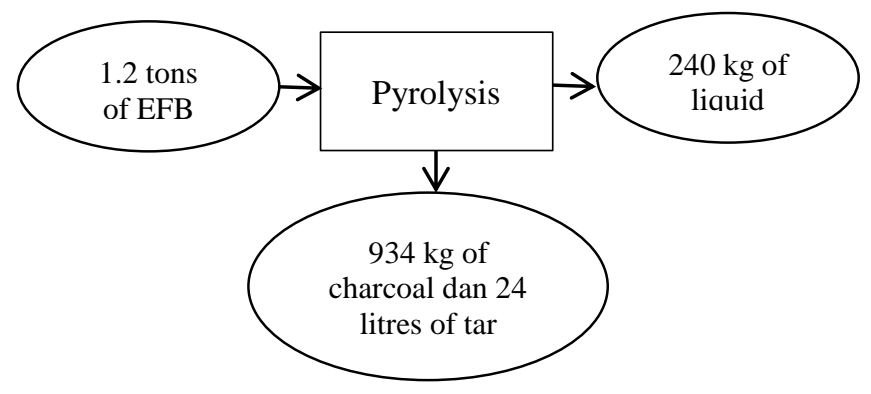

Fig. 1 Mass balance of EFB pyrolyis was compared to Gani, 2007 (29 percent of yield), showed that EFB pyrolisis of this research was lower in the liquid smoke production [12]. Gani (2007) stated that the yield of liquid smoke in the pyrolysis process was very dependent on the process conditions and the type of raw materials used. The yield percentage obtained were also very dependent on the temperature of pyrolysis and condensation systems used [12].

\section{Basis assumptions of Financal Feasibilty Analysis}

Basis assumptions of financial feasibilty analysis used are listed below:

- Financial analysis was conducted for 10 years period using straight line depreciation.

- The production capacity 1.200 tons of EFB produced liquid smoke and other materials in one day $240 \mathrm{~kg}$ of liquid smoke, 24 litres of tar, and $934 \mathrm{~kg}$ of charcoal respectively (Fig. 1).

- EFB price was Rp. 20,000/ton this was equal to raw material cost of Rp. 24,000/day. Energy cost for pyrolysis reactor was Rp.157.500/day

- Liquid smoke (C grade or non food grade) which was produced: Rp. 8,500/liter; tar Rp. 5,000/liter; and charcoal Rp. 2,000.kg..

- Bank interest rate was $14 \%$.

- Income taxes was calculated based on the Indonesia Minister of Finance regulation No.598 / KMK.04 / 1994 PPh 21 of the Enterprise Income Tax and Company. Hence that the amount of tax to be paid as follows: when the company suffered a loss that is not taxed if income <Rp. 25 million then taxed at $10 \%$, then when income between Rp. 25 million - Rp. 50 million then taxed $10 \%$ from Rp. 25 million plus $15 \%$ of the revenue that has been reduced by Rp. 25 million. then if the income is Rp. 50 million then set a tax of $10 \%$ from Rp. 25 million plus $15 \%$ of Rp. 25 million and coupled with $30 \%$ of the revenue that has been reduced by Rp. 50 million.

\section{Capital Sources and budgeting structure}

Budgeting structure and capital working were shown in the Table 1 .

TABLE 1

BUDGETING STRUCTURE AND CAPITAL WORKING OF LIQUID SMOKE INDUSTRY

\begin{tabular}{|c|c|c|c|c|c|c|}
\hline \multirow[b]{2}{*}{ No } & \multirow[b]{2}{*}{ Component } & \multirow{2}{*}{$\begin{array}{c}\text { Capital } \\
\text { Need } \\
(\mathbf{R p})\end{array}$} & \multicolumn{2}{|l|}{ Loan Capital } & \multicolumn{2}{|c|}{ Own Capital } \\
\hline & & & $\begin{array}{c}\text { Amount } \\
(\mathbf{R p})\end{array}$ & $(\%$ & $\begin{array}{c}\text { Amount } \\
(\mathbf{R p})\end{array}$ & $(\%)$ \\
\hline \multicolumn{7}{|c|}{1 Fixed Capital } \\
\hline & $\begin{array}{l}\text { a. Investment } \\
\text { Cost }\end{array}$ & $597,065,000$ & $417,945,500$ & 70 & $179,119,500$ & 30 \\
\hline & $\begin{array}{l}\text { b. Interest } \\
\text { During } \\
\text { Construction } \\
\text { (IDC) }\end{array}$ & $64,869,590$ & $45,408,713$ & 70 & $19,460,877$ & 30 \\
\hline 2 & $\begin{array}{l}\text { Working } \\
\text { Capital }\end{array}$ & $357,364,800$ & $250,155,360$ & 70 & $107,209,440$ & 30 \\
\hline & Total & 1,019,299,390 & $713,509,573$ & & $305,789,817$ & \\
\hline
\end{tabular}

Yield of EFB pyrolisis in this research (20 percent of yield), 
Table 1 showed that the Investment costs were simulated as fixed capital and working capital. Fixed capital includes pre-operating costs and other expenses concerned with the development efforts of the project, namely the procurement of land, building, installation support, office equipment and transportation, pre-operation, licensing and interest expense during construction. Estimated cost of fixed capital incurred for the establishment of the liquid smoke industry is Rp. 661,934. 590, - (including IDC 14\%). Working capital included the required cost for project running which was consist of fixed costs and variable costs. Estimated annual working capital in this industry was Rp. 357,364,800.

The scheme of investment cost in the processing of EFB to become liquid smoke was simulated not completely covered from the own capital, but used a bank loan with an interest rate of $14 \%$ KUR. The Bank loan repayment and interest thereon will be made within a period of 10 years. The financing structure of capital and working capital with Debt Equity Ratio (DER) of 70:30.

\section{E. Financial Feasibility Results}

The results of financial feasibility analysis were shown in Table 2.

TABLE 2

FINANCIAL FEASIBILITY ANALYSIS OF LIQUID SMOKE

\begin{tabular}{ll}
\hline Criteria & Value \\
\hline NPV (Rp.) & $991,486,765$ \\
IRR (\%) & 3.59 \\
NET B/C & 2.50 \\
PBP (year) & 2.83 \\
\hline
\end{tabular}

NPV value indicates the level of profit from the difference between revenue and expenditure. Positive NPV value indicates the amount of profit, whereas a negative NPV value indicates the value of the losses due to the amount of expenditure is greater than the reception. The results of the financial analysis industry liquid smoke with the eligibility criteria NPV indicates a positive value, it indicated that the industry was feasible to be developed.

IRR analysis result indicated that the capital investment for industrial liquid smoke profitable than saving money in the bank. This was indicated by the value of IRR exceeded the Bank's interest rate of $14 \%$. This IRR value can be interpreted that by investing capital to liquid smoke industry will give benefit as long as the interest rate is not greater than the value of IRR.

$\mathrm{Net} \mathrm{B} / \mathrm{C}$ ratio showed the magnitude of the rate of profit compared to spending during the economic life of the business. Enterprises is declared as feasible if the $\mathrm{B} / \mathrm{C}$ ratio of the resulting greater than or equal to one. If the value is less than one, then the effort is declared as useless and it is not feasible to be developed. Based on the calculation criteria for net $\mathrm{B} / \mathrm{C}$ ratio is obtained that the industry deserves to be developed as the result of the net $\mathrm{B} / \mathrm{C}$ was greater than one In the liquid smoke industry based on TKKS as raw material, investment capital will be returned within a period of 2.83 years. After the invested capital back fully, then the profit will reach $100 \%$.

Based on this result (Table 1), Liquid Smoke Industry using EFB as raw material was feasible to be developed in Mesuji Regency, Lampung Province. All criteria met the rule of Feasible Criteria of a Project [9].

\section{F. Break Even Point Analysis}

This analysis is used to determine the minimum amount of revenue that must be met in order that the business is at break-even point (BEP) at the level of business or no profit [8]. Based on the calculation, the BEP for liquid smoke industrial using EFB as raw material was Rp. 158,920,407 or equal to 18,697 tons of liquid smoke. It means that only around $13 \%$ of production capacity, BEP would be met. Compared to liquid smoke from coconut shell [12], BEP of liquid smoke production would be around $50 \%$.

\section{G. Sensitivity Analysis}

The sensitivity analysis performed for the numerous possible due to factors such as changes in component costs and prices fluctuated [8]. The results of sensitivity analysis showed that changes in prices of raw materials and auxiliary materials which increased up to to 36 $\%$ showing that the business is still feasible. Meanwhile, for the decline in selling prices up to $36 \%$ showed businesses are not feasible based on

NPV, IRR, and Net B/C and PBP criteria. The results of financial feasibility analysis were shown in Table 3.

TABLE 3.

SENSITIVITY ANALYSIS OF LIQUID SMOKE

\begin{tabular}{lllll}
\hline & \multicolumn{4}{c}{ Value } \\
\cline { 2 - 5 } Parameters & NPV (Rp) & $\begin{array}{l}\text { Net } \\
\text { B/C }\end{array}$ & $\begin{array}{l}\text { IRR } \\
(\%)\end{array}$ & $\begin{array}{l}\text { PP } \\
\text { (year) }\end{array}$ \\
\hline $\begin{array}{l}\text { 36\% increase on raw } \\
\text { materials prices }\end{array}$ & $984,703,494$ & 2.49 & 36.46 & 2.84 \\
$\begin{array}{l}\text { 36\% increase on } \\
\text { supporting materials }\end{array}$ & $811,306,126$ & 2.23 & 33.00 & 3.05 \\
$\begin{array}{l}\text { 36\% decrease on } \\
\text { product selling price }\end{array}$ & $148,102,785$ & 0.78 & 9.71 & 6.90 \\
$\begin{array}{l}\text { Combination of 36\% } \\
\text { decrease on selling price } \\
\text { and production quantity }\end{array}$ & $35,066,696$ & 0.49 & 3.61 & 10.51 \\
\hline
\end{tabular}

Sensitivity analysis on the liquid smoke industry calculated on the price increase, the increase in the price of supporting materials and sales price decrease by $36 \%$. This sensitivity number was decided with the trial and error method to get the minimum eligibility criteria for investment. The results of the sensitivity analysis in changing of raw materials and supporting materials prices which increased to $36 \%$ showed that the business was still feasible. As for the decline in selling prices down to $36 \%$ showed that the business was not feasible viewed from the eligibility criteria, namely NPV, IRR, and net $\mathrm{B} / \mathrm{C}$ which were not fulfilled the feasible values. But in PBP criteria, it was still within the feasible limit since it was smaller than the limit on the return time of investment. 
The sensitivity analysis of a combination from the changes in prices showed that all components of the project indicated the eligibility criteria were not feasible to develop. Liquid smoke industry based on TKKS quite sensitive to product prices. This was caused the sensitivity of the pyrolysis process of EFB does not only generate liquid smoke, but also produces tar and charcoal which also have economic value. Therefore, when the selling price has decreased, the profit margins are also getting smaller.

\section{CONCLUSION}

The liquid smoke industry from EFB was feasible to be developed with eligibility criteria are Rp. 991,486,765 of NPV; 2.50 of Net B/C; $36.59 \%$ of IR ; and 2.83 years of PBP. The results of sensitivity analysis showed that the liquid smoke industry from EFB more sensitive for liquid smoke price decerasing than raw material and other inputs price increasing.

\section{REFERENCES}

[1] A.G. Haji "Komponen Kimia Asap Cair Hasil Pirolisis Limbah Padat Kelapa Sawit”. Jurnal Rekayasa Kimia dan Lingkungan. Vol 9 (3): 109 $-116.2013$

[2] U. Hasanudin, T.P.Utomo and E. Suroso. "Pedoman Pengelolaan Limbah Industri Pengolahan Kelapa Sawit". Booklet. State Ministry for the Environment, Repubic of Indonesia. Jakarta. 2010.

[3] T. Utomo. "Pengaruh Rasio Asap Cair TKKS : Lateks Terhadap Parameter Fisik Bokar". Bachelor Theses., The Lampung University, Bandar Lampung. 2013.

[4] W.Satyajaya, E.Suroso, H.A.Rasyid and T.P. Utomo. Study of Leading Commodity Decision on rural Agro-industry Development in Tulang Bawang Regency. J.Inovasi dan Pembangunan. Vol 4(1): 22-36. 2016

[5] http://www.cpeo.org/techtree/ttdescript/pyrols.htm (accessed June 15, 2016).

[6] http://www.fao.org/docrep/t4470e/t4470e0a.htm (accessed June 15, 2016).

[7] Wanto, nnd D.R.W. Umboh D.R.W. "Modul Pembelajaran Pemanfaatan serta pemasaran Briket dan Asap Cair (Diklat Teknologi pada Guru)". Pusat Pengembangan dan Pemberdayaan Pendidik dan Tenaga Kependidikan Bidang Mesin dan Teknik Industri (PPPPTK BMTI). Bandung. 2014.

[8] Badan Pusat Statistik. Perkebunan Provinsi Lampung. Komoditas Perkebunan Unggulan (komoditi Sawit). Lampung. 2015.

[9] J.E. Austin. Agroindustrial Project Analysis. The John Hopkins University Press, Baltimore, Maryland. 1981.

[10] Dinas Perkebunan Provinsi Lampung. 2015. Data Statistik Produksi Kelapa Sawit. Lampung.

[11] Dinas Perkebunan Provinsi Lampung. 2015. Data Statistik Produksi Karet. Lampung.

[12] A. Gani, "Konversi Sampah Organik Menjadi Komarasca (KomposArang Aktif-Asap Cair) dan Aplikasinya pada Tanaman Daun Dewa Disertasi. Bogor: Sekolah Pascasarjana IPB. 2007. 